\title{
Human Dorset Remains from Igloolik, Canada
}

\author{
NIELS LYNNERUP, ${ }^{1}$ JØRGEN MELDGAARD, ${ }^{2}$ JAN JAKOBSEN, ${ }^{3}$ MARTIN APPELT, ${ }^{2}$ ANDERS KOCH ${ }^{4}$ \\ and BRUNO FRØHLICH ${ }^{5}$
}

(Received 19 February 2002; accepted in revised form 11 March 2003)

\begin{abstract}
Skeletal remains of four Dorset Palaeo-Eskimo individuals were found at Alarnerk (NhHd-1), Melville Peninsula, in 1954 by the joint Danish National Museum-University of Pennsylvania Expedition, which was excavating Dorset and preDorset sites. These remains included one complete mandible, two fragmentary mandibles, and a cranial fragment. One of the mandibular fragments, found in a grave, was from a child approximately nine months old. The other remains were found in middens at the site. These remains add to the otherwise very sparse Dorset human material. Analysis of the dental morphology, as well as morphometric analysis of the complete mandible, shows Eskimoid characters and resemblance with later period Greenlandic human skeletal remains.
\end{abstract}

Key words: graves, Alarnerk (NhHd-1), early and late Dorset, physical anthropology, dental anthropology

RÉSUMÉ. En 1954, à Alarnerk (NhHd-1) dans la péninsule de Melville, l'expédition menée conjointement par le Musée national du Danemark et l'université de Pennsylvanie pour effectuer des fouilles sur des sites de culture dorset et pré-dorset, a mis au jour des restes humains appartenant à quatre individus du paléo-esquimau du Dorset. Ces restes comprenaient une mâchoire inférieure complète, deux mâchoires inférieures partielles et un fragment de crâne. L'un des fragments mandibulaires, trouvé dans une sépulture, appartenait à un enfant âgé d'environ neuf mois. Les autres restes ont été découverts dans des tertres localisés sur le site. Ces restes viennent s'ajouter aux très rares éléments humains du Dorset déjà mis au jour. L'analyse de la morphologie dentaire du mandibule complet, ainsi que son analyse morphométrique, révèle des caractères esquimoïdes et une ressemblance avec des restes de squelettes humains groenlandais datant d'une période postérieure.

Mots clés: sépultures, Alarnerk (NhHd-1), Dorset ancien et Dorset tardif, anthropologie physique, anthropologie dentaire

Traduit pour la revue Arctic par Nésida Loyer.

\section{INTRODUCTION}

While the material culture of the Dorset people is well known from most parts of the Eastern Arctic, little is known of the people themselves. The remains of only 20 Dorset palaeo-Eskimo individuals have been reported so far (see Table 1). Hypotheses that have been put forward to explain the scarcity of Dorset skeletons include (1) they left their dead on the sea-ice, or (2) they left them uncovered on the tundra (Maxwell, 1985; McGhee, 1996:147). This study describes the skeletal remains of four Dorset individuals from Alarnerk (NhHd-1, Alaniq in Inuktitut transliteration), Melville Peninsula, Nunavut, Canada, currently curated by the Laboratory of Biological Anthropology at the University of Copenhagen, Denmark. (While all other archaeological materials from the excavations at
Alarnerk are housed at the Canadian Museum of Civilization, the skeletal material is currently in the process of being repatriated to the appropriate Canadian authority.)

Alarnerk is located on the northeast corner of the Melville Peninsula (Fig. 1). At this location, in 1954, Meldgaard discovered 208 Dorset houses along $2.5 \mathrm{~km}$ of coastline (Fig. 2). The houses were located on raised limestone beach ridges from 8 to $22 \mathrm{~m}$ above sea level. The typology of the collected materials indicated a gradual development in material culture from the $22 \mathrm{~m}$ terrace down to the latest traces at $8 \mathrm{~m}$, covering a time span from early to terminal Dorset. In 1957-58, the Copenhagen dating laboratory (The Radiocarbon Dating Laboratory at the National Museum of Denmark and Geological Survey of Greenland) performed four radiocarbon measurements on samples from Alarnerk, while two samples were analyzed by the

\footnotetext{
${ }^{1}$ Laboratory of Biological Anthropology, Institute of Forensic Medicine, University of Copenhagen, The Panum Institute, Blegdamsvej 3, DK-2200 Copenhagen, Denmark; n.lynnerup@antrolab.ku.dk

${ }^{2}$ SILA: The Greenland Research Centre at the National Museum of Denmark, Nationalmuseet, Frederiksholms Kanal 12, DK-1220 Copenhagen, Denmark

${ }^{3}$ Laboratory of Dental Anthropology, Institute of Odontology, University of Copenhagen, The Panum Institute, Blegdamsvej 3, DK-2200 Copenhagen, Denmark

${ }^{4}$ Dept. of Epidemiology Research, Danish Epidemiology Centre, Statens Serum Institut, Artillerivej 5, DK-2300 Copenhagen S, Denmark

${ }^{5}$ Department of Anthropology, Smithsonian Institution, National Museum of Natural History, Washington, D.C. 20560, U.S.A.

(C) The Arctic Institute of North America
} 
TABLE 1. Dorset and Pre-Dorset human remains.

\begin{tabular}{|c|c|c|c|}
\hline Culture & Site name & Skeletal remains & Reference \\
\hline Dorset & Mansel Island & 1 adult male & Oschinsky, 1960 \\
\hline Dorset & Sugluk Island & 1 adult female & Oschinsky, 1960 \\
\hline Dorset & Alarnerk, Igloolik & 3 adults, 1 infant & Meldgaard, 1960 \\
\hline Dorset & Gargamelle Rockshelter & 4 adults, 3 infants, 1 new born & Harp and Hughes, 1968; Brown, 1988, cited in Renouf, 1999 \\
\hline Dorset & Port-aux-Choix 2 & 1 adult, 1 infant & Harp and Hughes, 1968 \\
\hline Dorset & Lanes Cove & 1 infant & Anderson and Tuck, 1974 \\
\hline Dorset & Crow Head Cave & 1 adult, 4 juveniles, 1 infant & Anderson and Tuck, 1974; Brown 1988, cited in Renouf, 1999 \\
\hline Dorset & Pumbley Cove & 1 adult & Anderson and Tuck, 1974 \\
\hline Pre-Dorset & North Devon Island & 1 prematurely born infant & Helmer and Kennedy, 1986 \\
\hline Pre-Dorset & Qeqertasussuk & 2 adults & Koch et al., 1996 \\
\hline
\end{tabular}

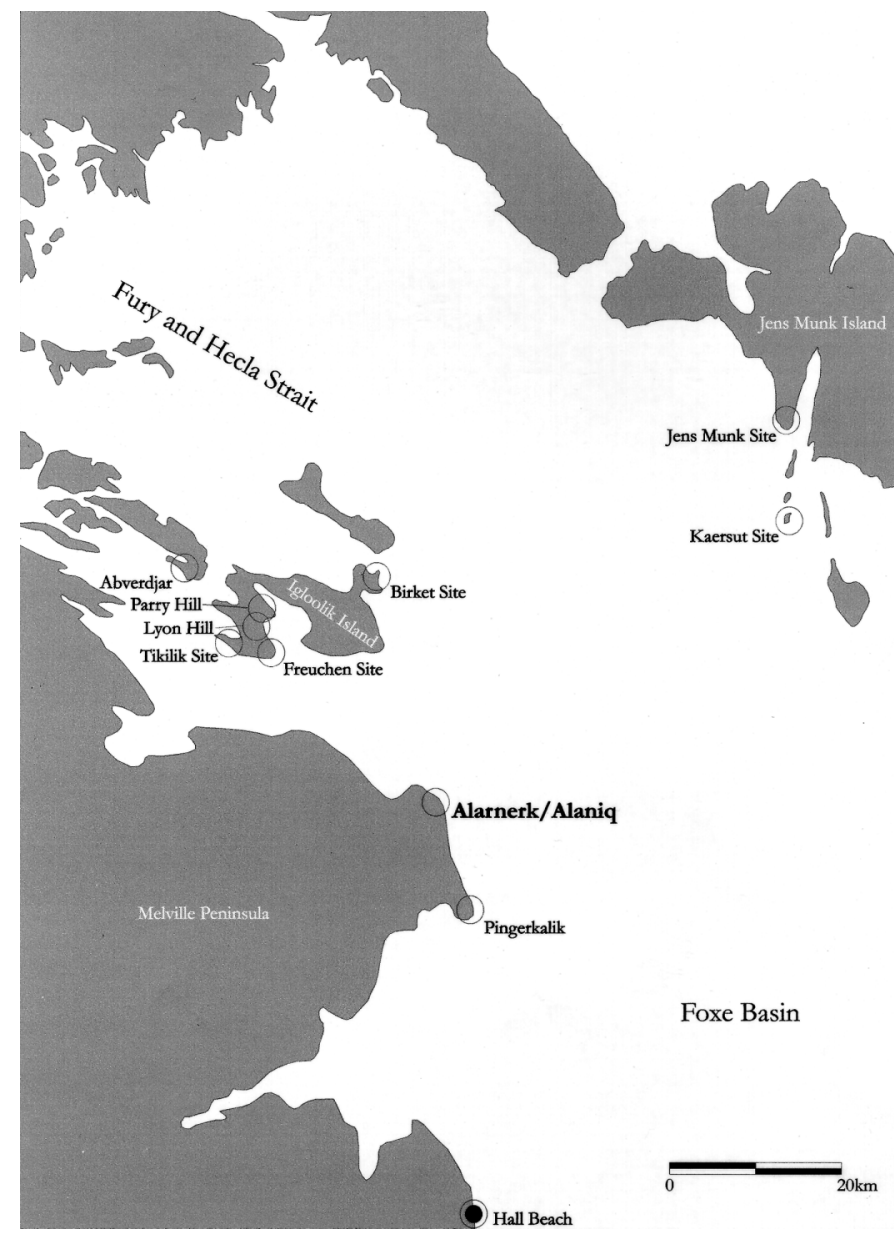

FIG. 1. The Igloolik area, showing pre-Dorset and Dorset sites located and mapped in 1954, 1957, and 1965. The Alarnerk site is southeast of Igloolik Island.

University of Pennsylvania dating laboratory. All samples but one were walrus ivory, so little can be done to adjust the dates to present-day standards. The radiocarbon datings may be found on the Canadian Archaeology website: www. canadianarchaeology.com/localc14/c14search.htm (look up site: Alarnerk).

However, the available radiocarbon dating - in combination with the relative beach terrace chronology from Alarnerk, the harpoon head typology developed by Meldgaard for northern Foxe Basin (Maxwell, 1985; Meldgaard, 1986:21-24), and more reliable radiocarbon datings from other Dorset sites-indicates a time span for the Dorset period at Alarnerk of approximately 800-600 B.C. to A.D. $1100-1200$. This paper presents the results of the anthropological specimens retrieved from Alarnerk in 1954, as well as pertinent contextual information. It is divided into three sections: The Graves, The Human Remains, and Discussion. The latter section will also focus on burial rituals.

\section{THE GRAVES}

Two types of graves seem to have been encountered at the site: chamber graves and pit graves. Aside from these graves proper, various other structures were identified at Alarnerk as Dorset "graves." Often these structures had been disturbed, and in several cases, they may not have been intended to contain human remains. Absence of human remains, however, does not exclude a function as secondary burials. When artifacts were found in connection to the graves, they always indicated activities carried out in a late Dorset period, contemporary with some of the 87 late Dorset houses situated $300-500 \mathrm{~m}$ away at the $14-$ $8 \mathrm{~m}$ levels: that is, the artifacts were not contemporary with the early Dorset activities otherwise found at the $22-21 \mathrm{~m}$ levels. These artifacts appear to have been carefully selected and were mostly non-utilitarian.

Every feature at Alarnerk was recorded in relation to the height above sea level of the beach terrace on which the feature was found; hence, 1520 is the 20th feature identified on the beach terrace at $15 \mathrm{~m}$ asl. Height above sea level was used by the excavators to establish a relative chronology - the so-called beach terrace chronology (for a more recent example of this, see Savelle and Dyke, 2002).

\section{The Chamber Graves}

At the highest levels of Alarnerk, some 21-22 m above sea level, were found a considerable number of chamberlike stone structures, all of which appear to be late Dorset graves. A total of 16 were mapped and assumed to be graves or arrangements related to burials, more or less disturbed by subsequent use as meat caches. The number of "graves" proper is uncertain, since meat caches dominate 


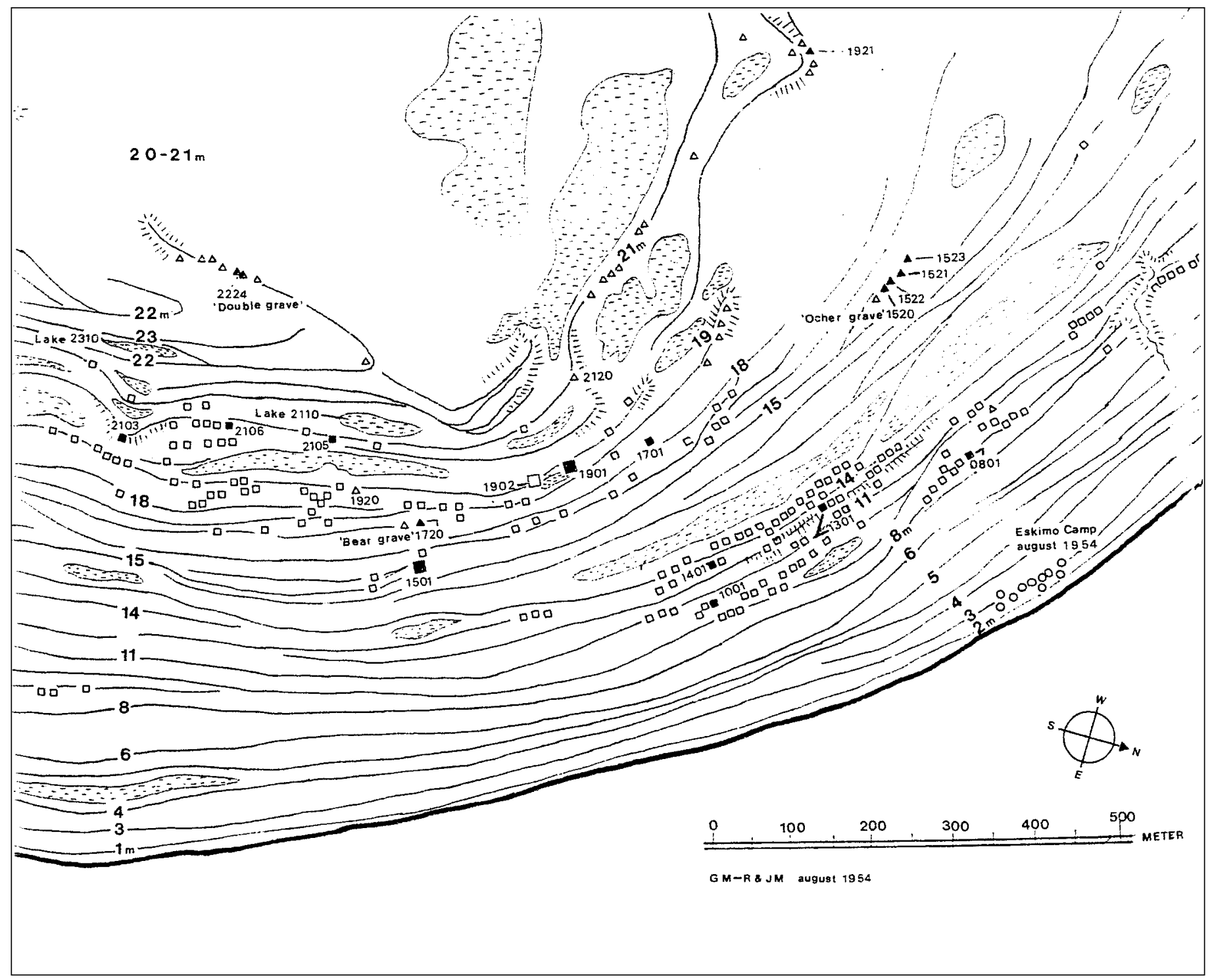

FIG. 2. Alarnerk, (Borden \#NhHd-1). Only the central area of the Dorset culture site is shown. A total of 208 house remains are distributed along the coast for $2.5 \mathrm{~km}$. Squares mark their position in relation to raised beach terraces. Triangles indicate Dorset graves and stone structures of different sorts. Many of the graves have been disturbed and reused as meat caches in later periods, and the exact number of Dorset graves cannot be established (Map drawn by Guy Mary-Rousselière and Jørgen Meldgaard). Filled triangles and squares indicate investigated features.

the barren gravel surfaces at these levels: some of them are still being used and rebuilt for walrus meat in the winter.

The few artifacts found scattered around and inside several of these stone arrangements are all of late Dorset origin, while the houses and middens otherwise found at the same levels date to the early Dorset period. In some cases, a small square or rectangular chamber, 1-1.4 m long and built of heavy stones, was preserved. No human remains were found in these chambers. A chamber of this size is too small to use as a cache for walrus meat, but fits with local tradition about Dorset graves. An old Inuit hunter, Alraq, our best informant in 1954 about Tunit people, told Father Guy Mary-Rousselière: “...our Inuit ancestors had long rectangular graves. The Tunit graves were very different: they were shorter and wider, and bigger stones were used for their walls..." (G. MaryRousselière, pers. comm. 1957).

\section{The Pit Graves}

Twelve presumed graves without large stone chambers, supposedly pit graves, were found on terraces from 15 to $19 \mathrm{~m}$ asl. The main feature was a rounded pit, $70-100 \mathrm{~cm}$ in diameter, dug 30-60 $\mathrm{cm}$ down in the gravel and lined with smaller stones and with flat stone plates in the bottom. A few artifacts, all of late Dorset origin, were found in these pits. On the terrace surface, they were marked only with one or two protruding stones or a slight depression, or both. Furthermore, five gravel mounds were observed in areas near pit graves: these were modest in height, consisting of a rounded and flattened heap of gravel $(2-9 \mathrm{~m}$ in diameter, with a maximum height of $0.8 \mathrm{~m}$ ) piled up on the ridge of the terrace. Two "mounds" were excavated, and both of them covered a "pit grave." Structures and artifacts 

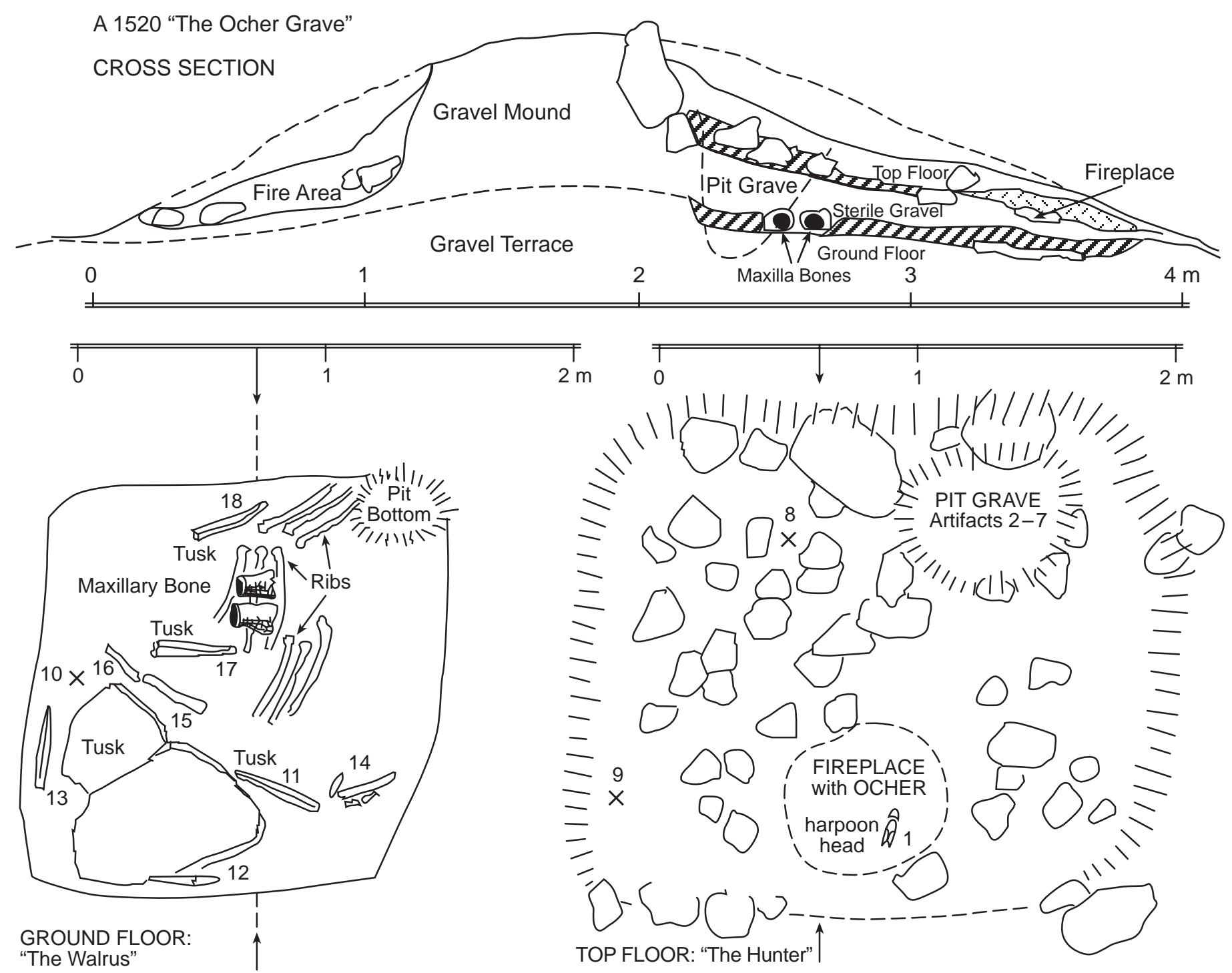

FIG. 3. Plan drawing of grave 1520. (J. Meldgaard, 1954, The National Museum of Denmark)

combined thus speak for activities relating to burial or ceremonies through which the spirits of the dead, man or animal, were assured an orderly transfer to another world. The well-preserved structure A1520 (the "ocher grave") is a pit grave that contained human remains, namely the child's jaw, marked \#4, AS 3/56). It is presented here as the most informative of the graves (Fig. 3).

\section{The Ocher Grave (A1520)}

On a terrace $15 \mathrm{~m}$ asl, a group of five structures was observed on the barren gravel ridge (see Fig. 2, A15201523). Three of them take the form of shallow depressions, interpreted as pit graves, approx. $1.5 \mathrm{~m}$ in diameter. The other two are small oblong mounds. A1520, one of the oblong mounds, was investigated and contained a child's jaw (AS 3/56). A complete list of associated artifacts is given in the Appendix.

The mound is oval, $9 \mathrm{~m}$ long in the direction of the terrace, $4 \mathrm{~m}$ wide, and has a maximum height of $0.8 \mathrm{~m}$. The mound may originally have had a smaller diameter and been higher, as it is very likely that some of the gravel has slid from the top of the mound down the sides. In a $2 \times 2 \mathrm{~m}$ depression in the northwestern side of the mound, a few stones were protruding. Excavation of this area revealed a $20-30 \mathrm{~cm}$ thick layer of fist- to head-sized stones, many of which had been blackened and cracked by fire. Animal bones of walrus, seal, and caribou, some marrow-split, were scattered among the stones, where a few artifacts were also found. A fireplace $(50-60 \mathrm{~cm})$ near the center of the depression was covered with a thin layer of ocher. A harpoon head (\#1) engraved with a human face was placed on top of the fireplace. A pit had been dug in the western corner of this $4 \mathrm{~m}^{2}$ activity area. It was $60 \mathrm{~cm}$ deep, rounded, filled up with black soil, and lined at the upper edge with a sooty layer of grease. The child's jaw and artifacts \#2-7 were found near the bottom of the pit.

Below the upper level was a deposit of sterile gravel $20-30 \mathrm{~cm}$ thick, which covered a lower culture layer, designated the "ground floor." The outline of this area 
TABLE 2. Measurements ( $\mathrm{mm}$ ) of the adult female mandible from Alarnerk, compared to average mandibular measures of females from the northwest, southwest, southeast and northeast coasts of Greenland (Frøhlich, 1979).

\begin{tabular}{|c|c|c|c|c|c|c|c|c|c|}
\hline \multirow[t]{2}{*}{ Measurements } & \multirow[t]{2}{*}{ Alarnerk \#3 } & \multicolumn{2}{|c|}{$\mathrm{NW}$} & \multicolumn{2}{|c|}{ SW } & \multicolumn{2}{|c|}{$\mathrm{SE}$} & \multicolumn{2}{|c|}{$\mathrm{NE}$} \\
\hline & & Avg. & $\mathrm{SD}$ & Avg. & $\mathrm{SD}$ & Avg. & $\mathrm{SD}$ & Avg. & $\mathrm{SD}$ \\
\hline Mental height & 30.0 & 33.2 & 3.75 & 32.4 & 3.69 & 32.9 & 2.71 & 35.7 & 3.85 \\
\hline Maximum length & 102.0 & 105.4 & 6.23 & 101.8 & 5.63 & 106.8 & 4.19 & 110.9 & 5.51 \\
\hline Maximum bigonial length & 74.0 & 76.0 & 6.35 & 75.3 & 4.06 & 78.6 & 3.82 & 81.3 & 4.17 \\
\hline Vertical height of rami & 48.0 & 47.0 & 7.06 & 47.8 & 5.16 & 48.3 & 3.64 & 47.9 & 4.35 \\
\hline Oblique height of rami & 55.0 & 53.6 & 6.05 & 51.4 & 4.48 & 52.9 & 3.67 & 53.4 & 3.87 \\
\hline Minimum ramus width & 39.0 & 37.6 & 3.75 & 36.5 & 2.55 & 38.9 & 2.56 & 39.2 & 1.97 \\
\hline
\end{tabular}

followed that of the square upper floor, though it was slightly smaller. It was dug $10-20 \mathrm{~cm}$ into the original surface of the terrace, and various bones and artifacts had been carefully placed on this "floor." Parts of a walrus seem to have a central position: The maxillary bones were split, but the sockets were placed close together on top of three walrus ribs. Two ivory tusks were split lengthwise in four parts (with a burin-like tool), and two of them were placed close to the maxillary bones. Six walrus ribs were arranged behind the maxillary bones in two groups. The pattern resembled a skeleton design. In the eastern corner, large, flat limestone plates covered with black soil were probably the base of a fireplace. Besides the bones incorporated into the skeletal design, a thin layer of primarily walrus bones (vertebrae and ribs) was found covering the floor. In contrast to the bones on the upper level, none of these bones were broken or split for marrow. Artifacts \#10-16 were placed near this fireplace, along with a human long bone, probably a femur. This bone is mentioned in Meldgaard's diary, but it has not been possible to locate the femur among the Laboratory's collections, and no records in the files of the Laboratory mention this bone.

On the southeastern side of the mound, a shallow depression revealed a floor with scattered stones, $1.1 \times 1.7 \mathrm{~m}$, and traces of fire. The arrangement was similar to that on the upper level described above, but no distinct fireplace, no pit, and no artifacts were found.

\section{THE HUMAN REMAINS}

The human remains comprise one complete mandible, two fragmentary mandibles, and a cranial fragment. Only one of these specimens, a mandibular fragment of a child, was found in the grave, while the others were recovered from midden deposits. In the following section, the numbering "Alarnerk \#1-\#4 AS 3/56" refers to the Laboratory inventory numbers (the bones were deposited at the Laboratory in 1956).

Alarnerk \#1, A2106, AS 3/56

The specimen consists of the mental region of a mandible (Fig. 4a). It was retrieved from a midden near house \#2106 (see Fig. 2), and is probably contemporaneous with the house (i.e., early Dorset). The fragment is not very robust, and its overall dimensions are small (see Table 2). The right canine and the first and second incisors were lost ante mortem. The sockets that formerly held the first permanent molar and the first and second premolars are visible on the right side. On the left side, the sockets from the first and second incisors, the canine, and the two premolars are visible. All sockets are shallow, indicating secondary eruption due to dental wear. In the sockets from the right first permanent molar, a relic from a supernumerary disto-lingual root, characteristic of Mongoloid dentition (Pedersen, 1949), is present. Furthermore, pronounced mandibular tori occur on the lingual sides of the specimen. The missing right canine (a radiograph did not show an impacted tooth) and the loss of the two lower right incisors, combined with the very shallow sockets from the left incisors, may indicate that the remains are from an older adult. The gracile morphology, as well as the overall dental and skeletal dimensions, may indicate that the person was female.

\section{Alarnerk \#2, A0801, AS 3/56}

This is a cranial fragment of the left parietal bone of an adult individual (Fig. 4b), retrieved from a late Dorset midden at house \#0801 (Fig. 2). Suture indentations are visible on the medial edge, indicating that the sagittal suture was not ossified at the time of death. The sex could not be determined.

\section{Alarnerk \#3, A2103, AS 3/56}

This is an intact mandible (Fig. 4c), retrieved from a midden near house \#2103 (Fig. 2) and therefore probably early Dorset. Three permanent molars were found in situ on both sides of the jaw, while 10 anterior and permanent teeth were lost post mortem. The teeth are only slightly worn; the dentine is exposed on one mesial cusp on the first right and left permanent molars. Radiographic and visual inspection of the roots of the third molars revealed that the root apices were fully developed, but not completely closed. This finding allowed us to estimate the age at death to be $18-22$ years. All molars were two-rooted. The observed teeth are all free of disease in the crown, roots, and surrounding bone. On the basis of the overall 

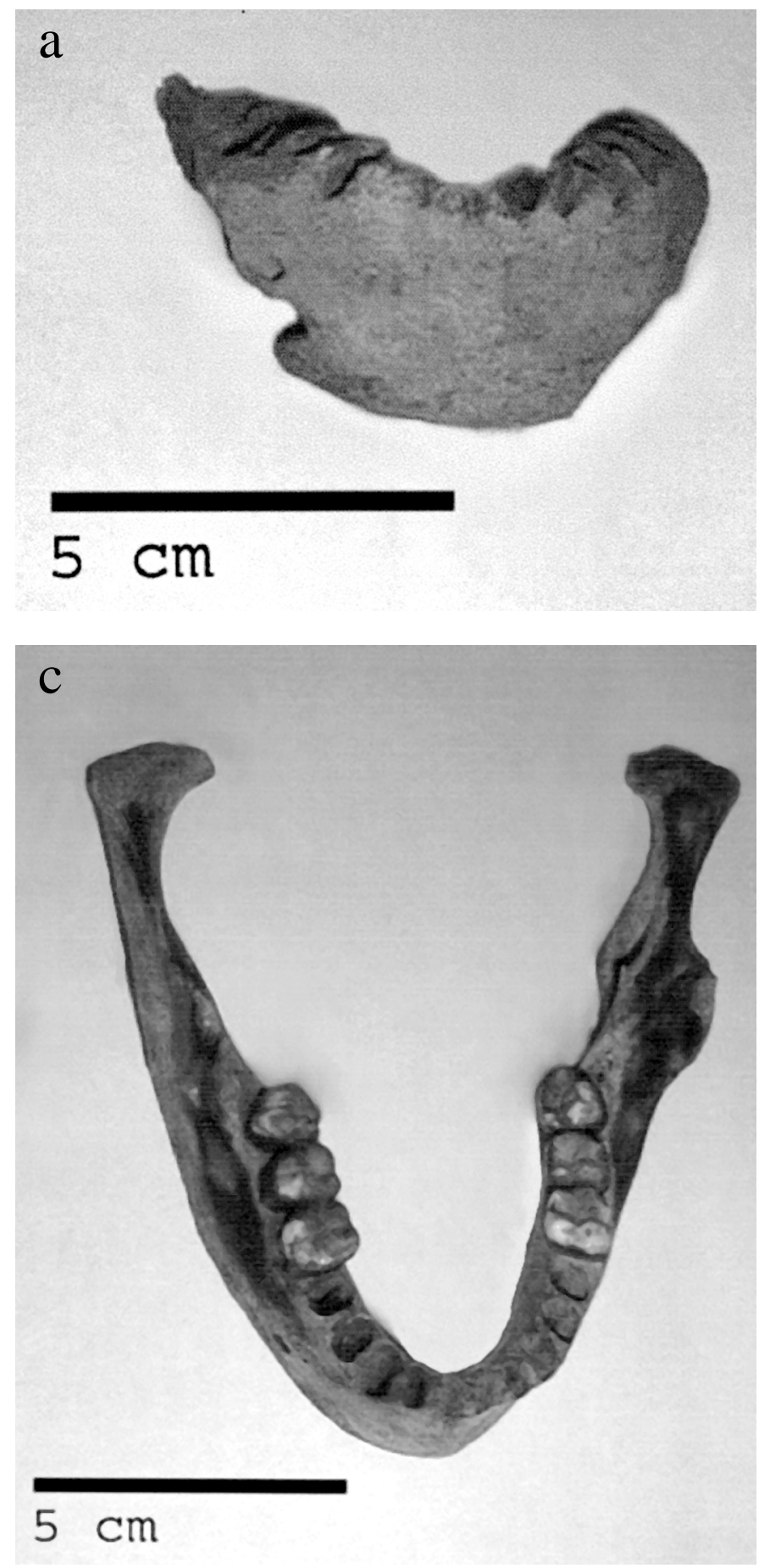

dimensions of the mandible and its general features, it was concluded that the mandible is from a female.

\section{Alarnerk \#4, A1520, AS 3/56}

The body of a mandible of an infant (Fig. 4d), was retrieved from the "ocher grave" \#1520 (Fig. 2), a late Dorset feature. Only the base of the mandibular body and a fragment of the left mandibular ramus were preserved. The developing crowns of the left first and second temporary molars were present. The sockets of the temporal incisors were seen in the frontal part of the mandibula, and
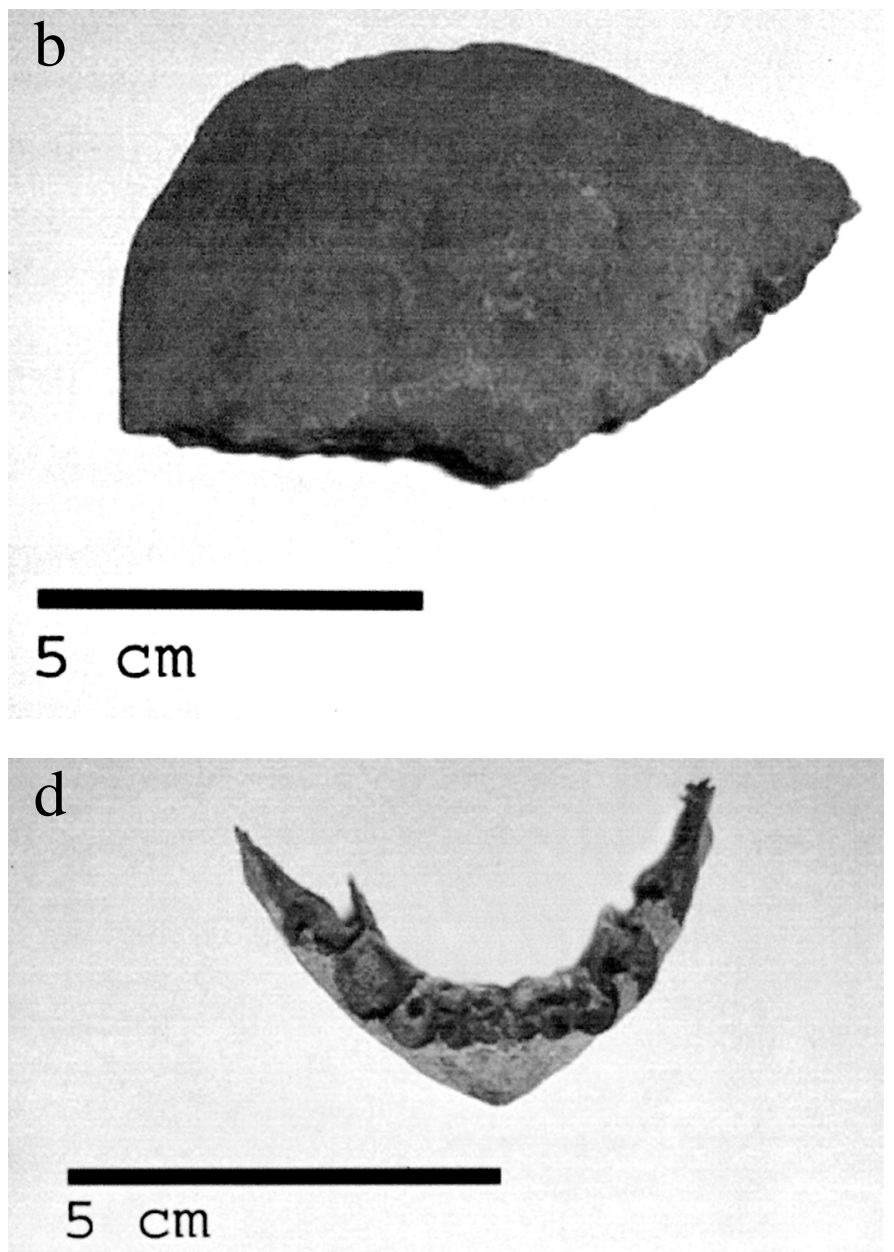

FIG. 4. a) Alarnerk \#1: Mental region of mandible, probably from an older female; b) Alarnerk \#2: Cranial fragment of adult; c) Alarnerk \#3: Mandible from a young female, probably 18-22 years old; and d) Alarnerk \#4: Mandibular fragment of an infant, probably nine months old.

behind these the tooth bud cavities of the four permanent incisors were formed in the alveolar bone. The dental conditions indicate that the infant was approximately nine months old at death. The second molar had a supernumerary cusp, and the first molar is of the triangular type, characteristics also noted by Alexandersen (1970) when he described this mandible.

\section{DISCUSSION}

\section{The Physical and Dental Anthropology}

The finding of Dorset human remains in Nunavut is exceptional. Until the present study, such finds comprised fragmented remains of only a premature pre-Dorset infant from Devon Island (Helmer and Kennedy, 1986). The remains of some 20 pre-Dorset and Dorset individuals are known from northern Quebec and Newfoundland (Laughlin and Taylor, 1960; Oschinsky, 1960, 1964; Harp and Hughes, 1968; Anderson and Tuck, 1974; Utermohle, 1984; Brown, 1988 in Renouf, 1999:48), while two or 

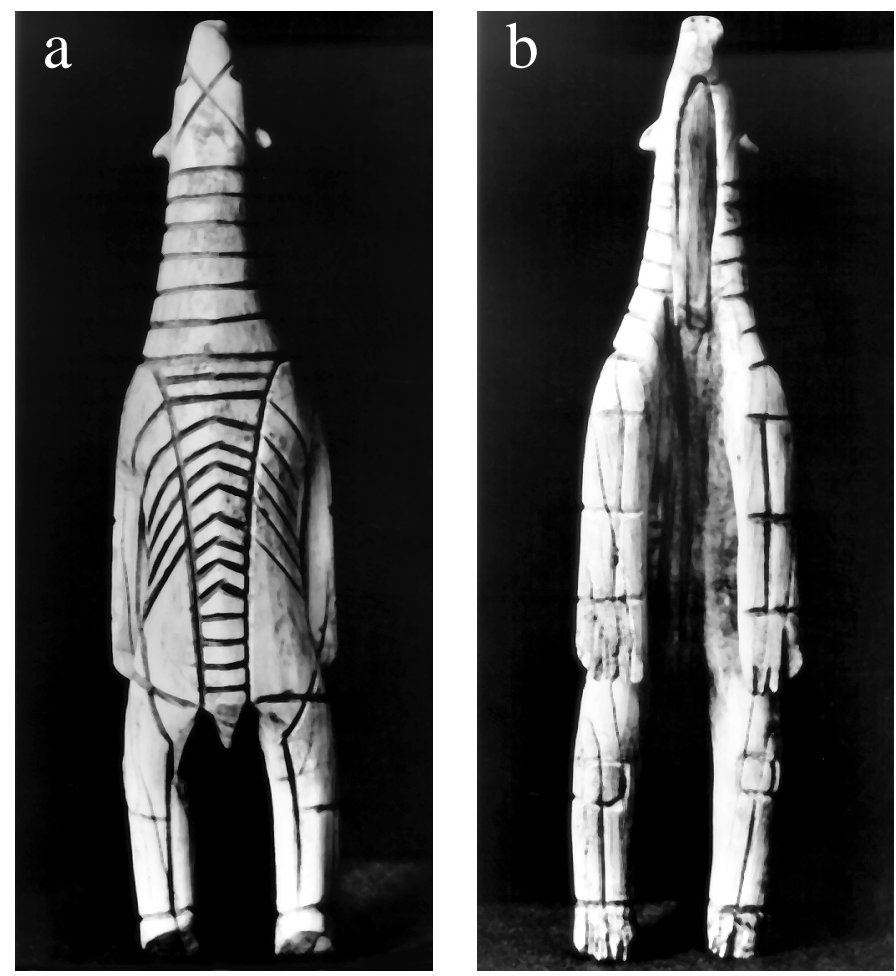

FIG. 5. a) back view and b) underside of the polar bear carving from grave 1720 . Notice the wooden slit in the throat region, which sealed off a small compartment containing ocher.

three adult Saqqaq culture individuals were found at Qeqertasussuk, West Greenland (Koch et al., 1996). Besides being few in number, these finds have a wide spatial and temporal distribution. Taylor identified the first probable Dorset burial in 1957 at the Imaha site (Laughlin and Taylor, 1960). However, the Imaha material has since been radiocarbon-dated, and the results are not consistent with the Dorset culture period (D. H. O'Rourke, pers. comm. 2001). The present finding is so far unique, as it represents the only known human remains of adult individuals from the Dorset culture in present-day Nunavut. The remains seem to comprise a mature female, probably early Dorset; a female, probably $18-22$ years of age and probably early Dorset; an adult individual, probably late Dorset; and a nine-month-old infant, probably late Dorset. Previous examinations of the material from northern Quebec and Newfoundland have indicated that the Dorset people were physically comparable to the Thule culture Inuit, characterized primarily by a large robust neurocranium, dolichocephaly, and marked cheekbones (Anderson and Tuck, 1974; Utermohle, 1984). In accordance with this, the dental morphology of the present material is consistent with the Mongoloid dental complex as described by Pedersen (1949). The presence of a supernumerary distolingual root on the first molar from individual \#1 suggests an Inuit affiliation in contrast to Native Amerindian, as this trait is more often found in Inuit than in Amerindians (Alexandersen 1970; Turner, 1991; Scott and Turner, 2000). In contrast, clearly apparent triangular

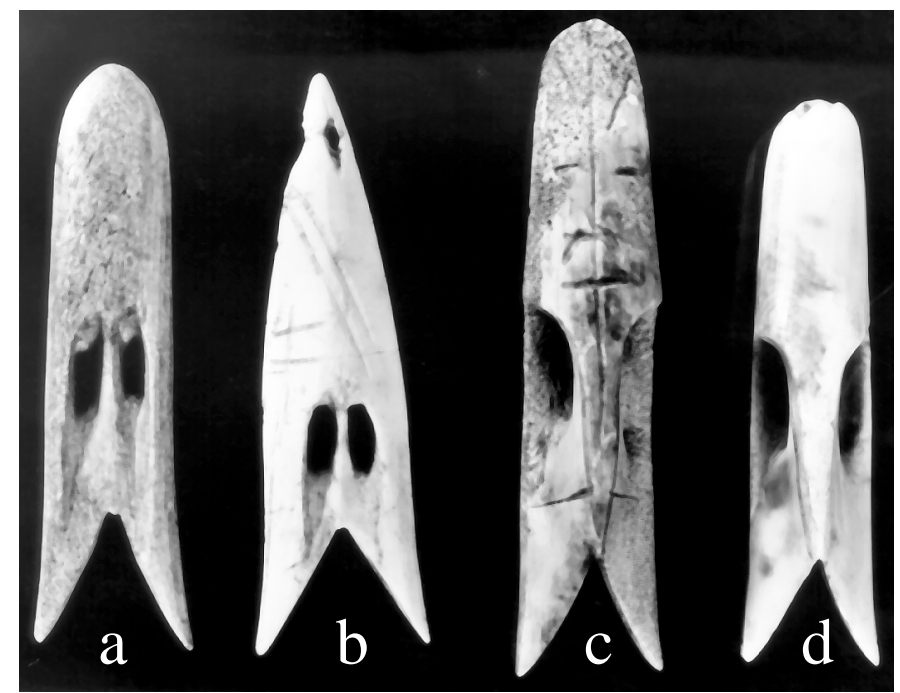

FIG. 6. Harpoon heads from the upper floor "pit" of grave 1520. The harpoon head (Fig. 6c) is $8.6 \mathrm{~cm}$ long. (J. Meldgaard, The National Museum of Denmark).

temporary first molars have been claimed as being more frequent in Amerindians than in Inuit (Dahlberg, 1963; Alexandersen, 1970). Therefore, from the available odontological data, it cannot be conclusively determined whether these individuals were more closely related to Inuit than to Amerindians. A number of activity-induced pathological changes in bones and teeth of Thule culture Inuit from Greenland and from Canada have been described (Merbs, 1983; Pedersen and Jakobsen, 1989), including loss of incisors and extensive tooth wear. The loss of lower incisors in the specimen Alarnerk \#1 could indicate a female who wore away her teeth through long-term preparation of skins (Pedersen, 1952; Pedersen and Jakobsen, 1989). No other pathological changes could be identified, and the causes of death remain unknown. In Table 2, metric variables from mandible Alarnerk \#3 are compared with anthropometric data from Greenlandic Inuit mandibles (Frøhlich, 1979; Frøhlich and Pedersen, 1992). The statistical means for many mandibular variables from several population groups, such as the Greenland west coast, southeast coast, northeast coast, and Aleut (by sex) can be found in Frøhlich (1979) and Frøhlich and Pedersen (1992). These means suggest that the Alarnerk data compare best to the female Southwest Greenland (pre-contact) group. Theories of "surviving" Dorset Inuit in southeastern Greenland have been suggested by Taylor (1967:16) and Taçon (1983:59), but this group shows least agreement with the Alarnerk mandible. However, only a single remain cannot contribute significantly to the discussions on the fate of the Dorset people (McGhee, 1978; Maxwell, 1985; Dumond, 1987:145; Krupnik, 1993:228; Cachel, 1997:588).

\section{The Burial Practices}

The Alarnerk site probably contains the largest number of palaeo-Eskimo graves found in the Eastern Arctic 


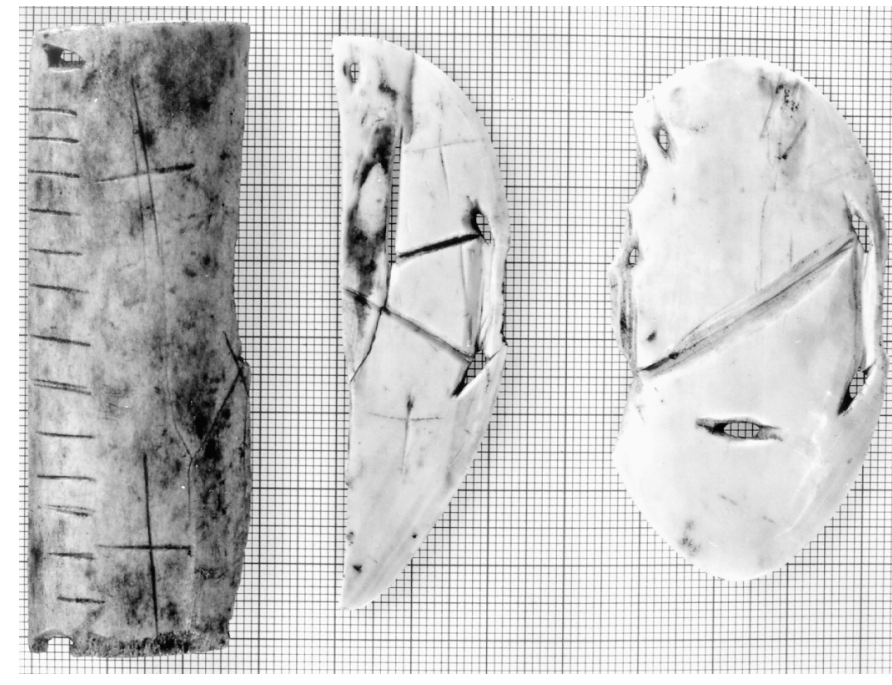

FIG. 7. Amulet box parts from the upper floor "pit" of grave 1520. The side piece is $8.2 \mathrm{~cm}$ long. (J. Meldgaard, The National Museum of Denmark)

(Meldgaard 1960, 1962). In comparison, several Dorset burials have been found in Newfoundland. The Dorset period Lanes Cove burial (Anderson and Tuck, 1974) was found in the vicinity of a settlement site, as is also the case for the Alarnerk material. On the other hand, the Crow Head and Pumpley Cove graves (Anderson and Tuck, 1974) and the Gargamelle Cove grave (Brown, 1988 in Renouf, 1999:48) were located in caves or crevices at some distance from known settlement structures. The preDorset burial from Devon Island was found within a settlement structure (Helmer and Kennedy, 1986). This is similar to the Port-aux-Choix 2 Dorset burial (Harp and Hughes, 1968). Also, these two burials included sub-adult material: a prematurely born infant and a 21-month-old child, respectively, and the latter also included an adult mandible, possibly from a secondary burial (Harp and Hughes, 1968). Unfortunately, Oschinsky (1960) does not include a description of the architecture and the cultural finds associated with the skeletal remains found on Mansel and Sugluk Islands. However, Maxwell (1985) states that the remains were found in middens. All of the burials described above, except those on Mansel Island and Sugluk Island, included artifacts. Also, all the graves seem to have been covered by stone slabs. The burials in caves include multiple individuals (Harp and Hughes, 1968; Anderson and Tuck, 1974). Brown (1988 in Renouf, 1999:48) has suggested that the burials at Crow Head Cave represented several burials that occurred in series, and not a single burial event (unlike the Gargamelle Rockshelter burial, which he believes represents individuals buried at the same time). Meldgaard's field observations suggest that at least two different coarse "types" of graves exist at the site. The first, and probably most recent, consisted of a short rectangular chamber of heavy stones paved with stone slabs, not unlike some of the Thule culture graves. The second type consisted of a pit dug into the gravel that was either covered by a low mound, like grave $\# 1520$, or lined

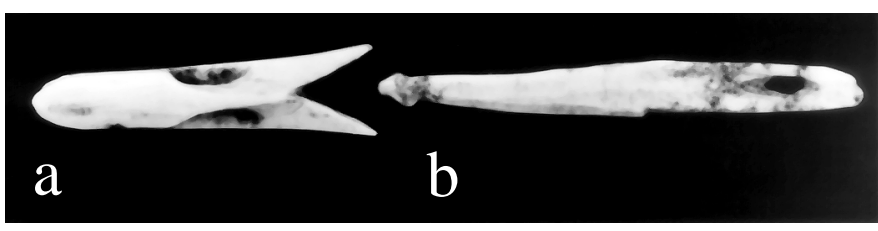

FIG. 8. a) Miniature harpoon head and b) foreshaft from upper floor level of grave 1520. The harpoon head is $2.5 \mathrm{~cm}$ long. (J. Meldgaard, The National Museum of Denmark)

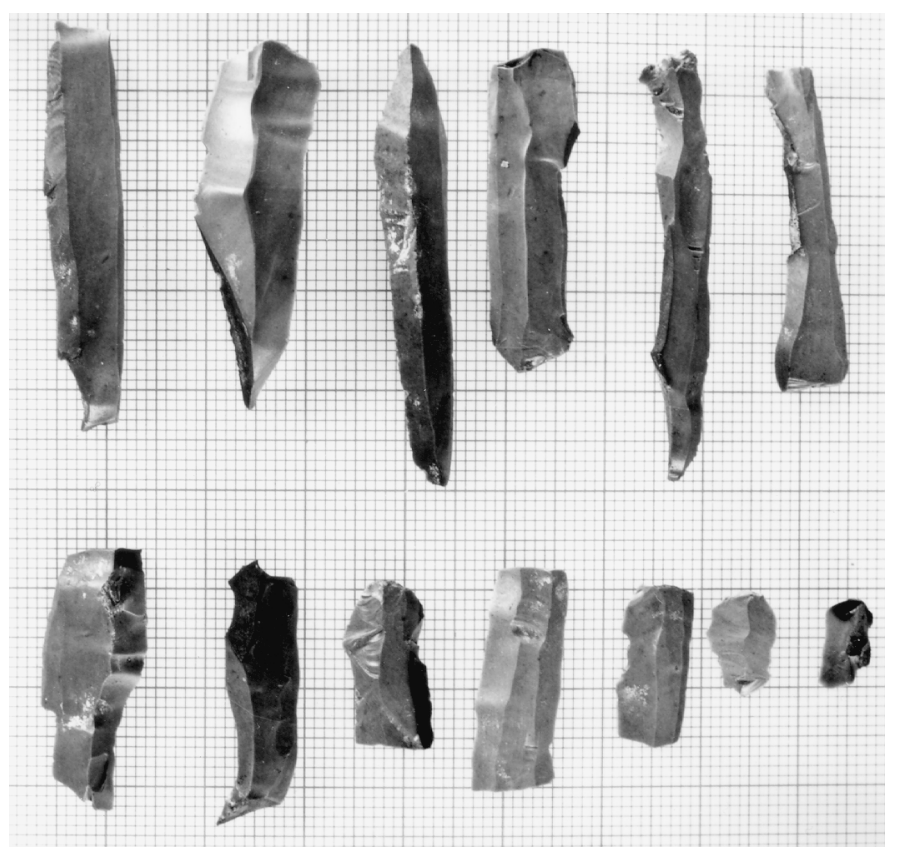

FIG. 9. Microblades from the lower floor level of grave 1520. The microblade in the top left corner is $4.1 \mathrm{~cm}$ long. (J. Meldgaard, The National Museum of Denmark)

by a few stones. The stratigraphy and the various arrangements found in \#1520 indicate activities on two or more occasions. The "ground floor" was prepared as the first step by clearing a square into the gravel ridge, which was then slightly excavated and flattened. Selected parts of a walrus were carefully placed in the square to form a pattern recognizable from the world of souls and spirits. Other bones of animals, probably the remains of a meal, were left on the floor. Also deposited were a few artifacts related to hunting, but crude and hardly functional. In advance, timeconsuming work had been devoted to treatment of the two walrus tusks, each of them being split lengthwise into two halves with a burin-like tool. The resulting heavy ivory specimens may not have had any practical function as tools. Two of them were then placed next to the maxillary bones, which were split in the same way by a burin-like tool, all together with ribs and vertebrae contributing to the "skeletal design." After ceremonies and activities centering on the large and important game animal, the floor was covered with gravel and the mound was probably formed. On this same occasion, the assumed incentive to all the activities, namely one or more deceased persons down at the village, might have been exposed somewhere under the 
open sky as the initial step in the burial practice. The top floor gave room for the human burial above the walrus burial, without disturbing the earlier arrangement. Two features, the pit and the fireplace, dominate the floor. Activities at the pit started with a heating process, possibly cooking, which left a rim of grease, soot, and gravel cemented together. The principal object, the human jaw, selected after a period of time from the remains of the exposed body, was placed in the pit, and artifacts including three harpoon heads followed the human remains. Meals based on cooked game, walrus, seal, and caribou were traceable as bones, partly burned, often broken and split for marrow. The close of activities appears to have been the spreading of the ocher on the fireplace, and, as a last deed, the placing on top of the fireplace of a harpoon head for walrus hunting decorated with a human face. The upper level was closed with gravel, leaving only a slight depression in the mound.

Apart from the graves proper, there remains the problem of interpreting the finds of skeletal elements in the middens, both at Alarnerk and Mansel and Sugluk Islands and at Qeqertasussuk. These elements could represent a mortuary practice of first laying the dead out for skeletonization and later choosing a few bones to be placed in a pit grave, along with grave goods (it should be noted that no cut-marks or evidence of carnivore scavenging were found on the bones). Indeed, Brown (1988, in Renouf, 1999:48) noted that: "the Dorset paleo-Eskimos may have accorded skulls special treatment in death, analogous to the way in which Inuit historically treated the heads of their prey animals in special ways as a mark of respect." While feature 1520 is a grave proper, it must still be regarded as a secondary mortuary phenomenon, as it contains only a part of the body. The bone from feature 0801, on the other hand, may be the remains of the primary step in handling the deceased. Still, as McGhee (1996:147) writes: "We simply don't know what rituals and practices surrounded an act that, in all societies, is fraught with anguish and trepidation."

This paper is a preliminary report on the human remains. With approval from the appropriate authorities, including prior repatriation, we suggest further analyses, especially radiocarbon dating of the bones themselves. Although we find that the human remains show a close Inuit affiliation overall, it is interesting that there have been previous reports on possible Amerindian dental traits (Alexandersen, 1970). Preliminary analysis of mitochondrial DNA from Dorset and Inuit skeletal materials from the Canadian Arctic suggests that genetic differences exist between the two groups, and that the now-extinct group of Sadlermiut people from Southampton Island may have had at least some genetic influx from palaeo-Eskimo groups (Hayes and O'Rourke, 2000). The Alarnerk Dorset skeletal material would be well suited to further testing of these hypotheses.

\section{POSTSCRIPT AND ACKNOWLEDGEMENTS}

The authors wish to thank the three anonymous reviewers for their invaluable critique. The second author of this article, who was the principal excavator, wishes to make the following remarks:

Father Guy Mary-Rousselière, OMI, was an indispensable collaborator during the excavations and mapping of the graves, unfolding here at Alarnerk his talent for archaeology and beginning a long career in Arctic anthropology. Our constant assistant and adviser Pacôme Qulaut took care of us in his home country for four months. By sledge and by boat, he guided us to the old sites he knew so well-beginning with Alarnerk. As a great hunter, he provided us with food all summer, and as local chief with authority, he provided experienced assistants for the excavations. Without Qulaut, no Dorset graves. One day in July, he left our camp for his private skin tent, where his wife gave birth to a son. That same day, the famous carving of a polar bear (grave 1720, see Fig. 5) was foundan occurrence to which the father attached importance.

\section{REFERENCES}

ALEXANDERSEN, V. 1970. Tandmorfologisk variation hos eskimoer og andre mongoloide populationer. Tandlægebladet 74:587-602.

ANDERSON, J.E., and TUCK, J.A. 1974. Osteology of the Dorset people. Man in the Northwest 8:89-97.

CACHEL, S. 1997. Dietary shifts and the European Upper Palaeolithic transition. Current Anthropology 38:579-604.

DAHLBERG, A.A. 1963. Analysis of the American Indian dentition. In: Brothwell, D.R., ed. Dental anthropology. Oxford: Pergamon Press. 138-176.

DUMOND, D.E. 1987. The Eskimos and Aleuts. London: Thames \& Hudson, Ltd.

FRØHLICH, B. 1979. The Aleut-Eskimo mandible. Ph.D. dissertation, University of Connecticut, Storrs, U.S.A.

FRØHLICH, B., and PEDERSEN, P.O. 1992. Secular changes within Arctic and Sub-arctic populations: A study of 632 human mandibles from the Aleutian Islands, Alaska and Greenland. Arctic Medical Research 51:173-195.

HARP, E., Jr., and HUGHES, D.R. 1968. Five prehistoric burials from Port aux Choix, Newfoundland. Polar Notes 8:1-47.

HAYES, G.M., and O'ROURKE, D.H. 2000. Molecular genetic characterization of the Dorset-Thule transition in the eastern Canadian Arctic. Paper presented at the 33rd Annual Meeting of the Canadian Archaeological Association, 3-7 May, Ottawa.

HELMER, J.W., and KENNEDY, B.V. 1986. Early Paleo-eskimo skeletal remains from North Devon Island, High Arctic Canada. Canadian Journal of Archaeology 10:127-143.

KOCH, A., FRØHLICH, B., LYNNERUP, N., and HART HANSEN, J.P. 1996. The bones from Qeqertasussuk: The earliest human remains from Greenland. In: Grønnow, B., ed. The Paleo-Eskimo cultures of Greenland: New perspectives in Greenlandic archaeology. Danish Polar Center Publications, No. 1. Copenhagen: The Danish Polar Center. 35-37. 
KRUPNIK, I. 1993. Arctic adaptations: Native whalers and reindeer herders of northern Eurasia. Hanover, New Hampshire: Dartmouth College/University Press of New England.

LAUGHLIN, W.S., and TAYLOR, W.E., Jr. 1960. A Cape Dorset culture site on the west coast of Ungava Bay. In: Contributions to Anthropology in 1958, National Museum of Canada Bulletin 168. 1-28.

MAXWELL, M.S. 1985. Prehistory of the Eastern Arctic. Orlando, Florida: Academic Press Inc. 327 p.

McGHEE, R. 1978. Canadian Arctic prehistory. Scarborough, Ontario: Van Nostrand Reinhold.

1996. Ancient people of the Arctic. Ottawa: Canadian Museum of Civilization and Vancouver: UBC Press.

MELDGAARD, J. 1960. Prehistoric culture sequences in the Eastern Arctic as elucidated by stratified sites at Igloolik. Selected papers of the 5th International Congress of Anthropological and Ethnological Sciences, 1956. Philadelphia: University of Pennsylvania Press. 588-595.

- 1962. On the formative period of the Dorset culture. In: Campbell, J., ed. Prehistoric cultural relations between the Arctic and the Temperate zones of North America. Technical Paper 1. Montreal: The Arctic Institute of North America. 92-95.

- 1986. Dorsetkulturen: Udviklingstendenser og afbrydelser. In: Vort Sprog - vor kultur. Pilersuffik, Nuuk. 15-31.

MERBS, C.F. 1983. Patterns of activity-induced pathology in a Canadian Inuit population. Archaeological Survey of Canada, Paper No. 119. 199 p.

OSCHINKSY, L. 1960. Two recently discovered human mandibles from Cape Dorset sites on Sugluk and Mansel Islands. Anthropologica 2:212-227.
- 1964. The most ancient Eskimos. Canadian Research Centre for Anthropology. Monograph. Ottawa: The University of Ottawa.

PEDERSEN, P.O. 1949. The East Greenland Eskimo dentition. Meddelelser om Grønland 142. 256 p.

- 1952. Some dental aspects of anthropology. Dental Record 72:170-178.

PEDERSEN, P.O., and JAKOBSEN, J. 1989. Teeth and jaws of the Qilakitsoq mummies. Meddelelser om Grønland, Man \& Society 12. $112-129$.

RENOUF, M.A.P. 1999. Ancient cultures, bountiful seas. Newfoundland: Historic Sites Association of Newfoundland and Labrador.

SAVELLE, J.M., and DYKE, A.S. 2002. Variability in Palaeoeskimo occupation on southwestern Victoria Island, Arctic Canada: Causes and consequences. World Archaeology 33(3):508-522.

SCOTT, G.R., and TURNER, C.G., II. 2000. The anthropology of modern human teeth. Cambridge: Cambridge University Press. $406 \mathrm{p}$.

TAÇON, P.S.C. 1983. An analysis of Dorset art in relation to prehistoric culture stress. Etudes/Inuit Studies 7(1):41-65.

TAYLOR, W.E., Jr. 1967. The silent echoes of culture. In: Prehistoric art: A discussion by an archaeologist and an artist. The Beaver 298 (Spring):4-19.

TURNER, C.G., II. 1991. The dentition of Arctic peoples. New York: Garland Publishing, Inc.

UTERMOHLE, C.J. 1984. From Barrow eastward: Cranial variation of the Eastern Eskimo. Ph.D. thesis, Arizona State University, U.S.A.

\section{APPENDIX: LIST OF ARTIFACTS FROM GRAVE 1520}

The artifacts are numbered from 1 to 18 . Some numbers are composite or comprise several specimens.

\section{The Upper Floor}

1) An ivory harpoon head for walrus hunting (Type E, state 19, Meldgaard, 1986:23), $8.6 \mathrm{~cm}$ long, with a triangular end blade of flint. Placed at top of fireplace (Fig. 6c).

2-7) Artifacts from the "pit grave." Found near bottom, 50-60 cm below surface, like the mandible of the infant.

2) An ivory harpoon head, $7.4 \mathrm{~cm}$ long (Same type and type-state as \#1, Fig. 6d).

3) An antler harpoon head, $7.6 \mathrm{~cm}$ long (Type G, Fig. 6a).

4) An ivory harpoon head, $7.4 \mathrm{~cm}$ long (Type F, Fig. 6b).

5) A walrus ulna "bone knife" with a blunt point, $14 \mathrm{~cm}$ long.

6) An "amulet box" of ivory and antler. The specimen is fragmented. The bottom piece is $6.9 \times 4 \mathrm{~cm}$; the lid is 7.5 $\times 4.4 \mathrm{~cm}$; and the sidepiece is $8.2 \mathrm{~cm}$ long (Fig. 7).

7) Ivory miniature harpoon head foreshaft, $3.6 \mathrm{~cm}$ long (Fig. 8b).

8) Ivory miniature harpoon head, $2.5 \mathrm{~cm}$ long (Type E, type-state 19, Fig. 8a).

9) Four microblades found close together, $3.8-4.1 \mathrm{~cm}$ long.

\section{The Lower Floor}

10) 13 microblades, $0.9-4.4 \mathrm{~cm}$ long, probably from the same core (Fig. 9).

11, 13, 17, and 18) Halved walrus tusks, split with a burin-like tool.

12) A heavy foreshaft, probably for a Type E harpoon head.

14) Knife or lance head, composed of a wooden shaft (crumbly), min. $16 \mathrm{~cm}$ long, two microblades as side blades (6.5 and $7.5 \mathrm{~cm}$ long), and a unifacial end blade $9.7 \mathrm{~cm}$ long.

15 and 16) Two parts of a foreshaft (?) of notched bone pieces - atypical. 